\title{
Working-Conditions, Stress and Their Outcomes: A Review Study among Loco-Pilots (Railway Drivers) in India
}

\author{
Rajesh Ranjan ${ }^{1}$, Dr. T. Prasad ${ }^{2}$ \\ 1. Fellow (Ph.D. Scholar), National Institute of Industrial Engineering (NITIE), Mumbai-400087. \\ 2. (Associate Professor), National Institute of Industrial Engineering (NITIE), Mumbai-400087.
}

\begin{abstract}
Stress is a normal part of human life in the modern world. The effect of stress is a deviation from the existing physical and psychological damage of human life. Stress is unavoidable and can occur in all facets of life. Stress that is prolonged and managed poorly can result in negative physical, mental, and cognitive outcomes for humans. Other negative outcomes include anxiety, depression, weakened immune system, heart disease, obesity, and poor memory. The aim of this paper is to identify the level of stress among Loco-Pilots (railway drivers) in India. The work of railway drivers is considered as extremely stressful and this paper deals with factors that lead to stress and fatigue and thus to high probability of accident. The aim of this paper is to bring an extensive review of knowledge on stress, fatigue and working conditions regarding to job out-comes of railway drivers.
\end{abstract}

Keywords: Railway driver, working-conditions, stress, fatigue, health risks and job outcomes.

\subsection{What is stress?}

\section{Introduction}

The term stress originates from physical science where it refers to the force placed upon an object to cause straining, bending, or breaking. In the human context and in psychology, however, stress is often used to describe the body's responses to demands placed upon it, whether these demands are favorable or unfavorable. Anything that causes stress is called a stressor (Khodabakhsh Ahmadi and Kolivand Alireza, 2007). In popular terms, stress is mainly defined as time pressure. We feel stressed when we do not have the time to perform the tasks that we want to perform within a given period. The perception of time pressure usually triggers a set of physiological reactions that indicate that we are stressed (Centre for Studies on Human Stress, 2007). Stress results from the tension between an individual's reaction to difficulties or challenges and his or her ability to handle and resolve the stressful situation. How people cope with stress depends on the resources that are available to them and whether they have the skills to utilize these resources. The term stressor relates to a challenging occurrence that may produce stress.

\subsection{Occupational stress}

Occupational stress, is the inability to cope with the pressures in a job (Rees, 1997), because of a poor fit between someone's abilities and his/her work requirements and conditions (Holmlund- Rytkönen and Strandvik, 2005). It is a mental and physical condition which affects an individual's productivity, effectiveness, personal health and quality of work (Comish and Swindle, 1994).

These are the following sources of occupational stress:

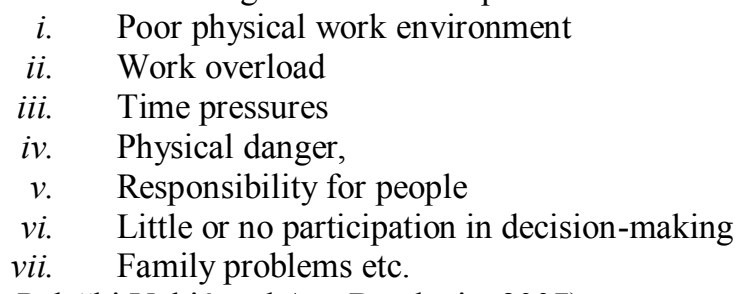

(Nina Pološki Vokić and Ana Bogdanic, 2007)

1.3 Consequences of occupational stress

Stress produces a range of undesirable, expensive, and debilitating consequences (Ross, 2005), which affect both individuals and organizations. 
1.3.1 On the individual level, there are three main subgroups of strains:

a) Unwanted feelings and behaviors - such as job dissatisfaction, lower motivation, low employee morale, less organizational commitment, lowered overall quality of work life, absenteeism, turnover, intention to leave the job, lower productivity, decreased quantity and quality of work, inability to make sound decisions, sabotage and work stoppage, occupational burnout, alienation, and increased smoking and alcohol intake.

b) Physiological diseases (poor physical health) - such as increased blood pressure and pulse rate, cardiovascular diseases, high cholesterol, high blood sugar, insomnia, headaches, infections, skin problems, suppressed immune system, injuries, and fatigue.

c) Psychological diseases (poor emotional (mental) health) - psychological distress, depression, anxiousness, passiveness/aggressiveness, boredom, lose of self-confidence and self-esteem, lose of concentration, feelings of futility, impulsiveness and disregarding of social norms and values, dissatisfaction with job and live, losing of contact with reality, and emotional fatigue (Nina Pološki Vokić and Ana Bogdanic, 2007).

1.3.2 On the organizational level, consequences of occupational stress can be grouped into two major subgroups:

a) Organizational symptoms - such as discontent and poor morale among the workforce, performance/productivity losses, low quality products and services, poorer relationships with clients, suppliers, partners and regulatory authorities, losing customers, bad publicity, damage to the corporate image and reputation, missed opportunities, disruption to production, high accident and mistakes rates, high labor turnover, loss of valuable staff, increased sick-leave, permanent vacancies, premature retirement, diminished cooperation, poor internal communications, more internal conflicts, and dysfunctional workplace climate.

b) Organizational costs - such as costs of reduced performance/productivity (lack of added value to product and/or service), high replacement costs in connection with labor turnover (increase in recruitment, training and retraining costs), increased sick pay, increased health-care costs and disability payments, higher grievance and litigation/compensation costs, and costs of equipment damage (Nina Pološki Vokić and Ana Bogdanic, 2007).

\subsection{Signs of stress}

When a person is experiencing difficulties coping with stress, he or she is likely to show changes in mood, behavior, and/or physical appearance. Physical changes include muscle tension, headache, stomachache, trouble sleeping, trouble eating, and lack of energy. Emotional changes include nervousness, anxiety, loss of enthusiasm about things he or she used to enjoy, anger or hostility towards peers, shyness or withdrawal, and feelings of helplessness and hopelessness. Behavioral changes include poor eating habits and excessive weight gain/loss over a short period of time (Mary Terzian et al; 2010).

1.4.1 What should you do if you think a person is experiencing difficulty with stress?

$\checkmark$ Provide or increase access to social support. Social support (in the form of emotional support, advice, assistance, and guidance) can reduce stress and improve coping skills.

$\checkmark$ Teach breathing and relaxation techniques. Breathing and relaxation techniques, such as deep breathing, yoga, and physical exercises, produce physiological changes (a slower heart rate and more relaxed muscles) that can help people to cope more easily with stress. They can also help to increase energy and focus, fight illness, and relieve aches and pains.

$\checkmark$ Encourage involvement in sports and other extra-curricular activities. Involving Person in positive pastimes, such as music and drama, arts and crafts, and religious activities, can help buffer stress or negative situations experienced in daily life.

(Mary Terzian et al; 2010)

\subsection{Stresses at work}

The stress is burning issue in modern society. The effect of stress is a deviation from the existing physical and psychological condition of human life. The stress is regarded as an inevitable consequence of employee functionality. The occupational stress adversely affects the health and performance of the employees of an organization. Stress harmfully impacts the human lives, including workers. According to Braaten Dan J. (2000), job stress can be defined as 'the harmful physical and emotional responses that occur when the requirements of the job do not match the capabilities, resources, or needs of the worker' (W.R.P.K. Fernando et al; 2013).

Those that are intrinsic to the job include long work hours, work overload, time pressure, difficult, demanding or complex tasks, lack of breaks, and poor physical work conditions (limited space, inconvenient temperature, limited or inappropriate lighting conditions) causes of stress (Jorn Bakker et al; 2013). 


\section{Loco-pilots (railway drivers) and stress}

The work of Indian railways' drivers is considered as extremely stressful. It is working in an environment over which they have no control whatsoever and is an atmosphere that wrecks their schedules, disrupts their home life, makes social activities and regular breaks very hard to plan. The work of the railway driver is demanding and full of responsibility. The railway driver is in- charge of both safety and punctuality, a job which requires a high level of concentration and alertness. The extremely irregular working hours constitute an added workload for the railway driver. The physical work environment can also give rise to workload; this includes, for eg; noise (or distressful noise levels), vibrations or an uncomfortable cab conditions (too hot, too cold, draughty). The railway driver is also exposed to a demanding psychosocial work environment, which includes solitary work, limited opportunities for social contact and a heavy responsibility for operating the train (in terms of both safety and adhering to the timetable). Railway drivers struggle to fulfill work and family responsibilities. This struggle is due to long hours, irregular and inflexible work schedules, and heavy workloads (Ranjan, R. and Prasad, T., 2013).

The train driving profession in general bears a wide range of stress-inducing factors (stressors). Quick decision-taking is required in situations of possible collisions (such as unexpected obstacle on the track), driving at night or in bad weather conditions, and is combined with the requirement of making a correct judgment of the situation and correct reaction. Kloimuller, I. (2000) distinguishes between three major classes of risk factors: high physical work demands (static muscle effort, repetitive movements), stressful or dangerous work environment (risk of accidents, great heat or cold) and poor organization of work (role conflicts, control, fear of failure, lack of recognition and esteem at work).

It is possible to say in general that biggest level of stress railway drivers' in India experiences, due to they have a high demand on work and in the same time limited possibilities of decision-making.

2.1 These are the concrete factors of stress in the case of Indian railway drivers:

$i$. Processing big amount of signals within a very short time segment (Averagely there are signals after every 1.5 Kilometer distance and gates averagely after every $1.3 \mathrm{~km}$ ). It means averagely after every 1 minute \& 22 seconds loco pilots must ready to observe signal. And after every 1 minute \&11 seconds loco pilot must be prepared to observe gates condition (Singh Ravi Kant, 2008). If he ignores any red signal and crossed it (while any accidents occurred or not), Railways authorities takes very strict action against him (loco-pilot) that might even lead to removal from service (Ranjan, $R$. and Prasad, T., 2013).

ii. Loco pilot must have sharp look out. While on run he must observe all permanent \& temporary speed restrictions.

iii. Continuous running for long hours. For example, Bihar Sampark Kranti Exp. (12565) runs between Darbhanga (Bihar) to New Delhi. Loco-pilot booked/sign-on his duty in Darbhanga and continuous running the train to Chhapra (That is around 202KM) and take around 5 hours continuous running /duty. And some other trains take around 5 to 6 hours for this distance. Table-3, (10 Hrs. Report), is showing the long working hours (Sign On to Sign Off) of Loco-Pilots in the month of Aug; 2013 of SEE (Sonpur) Lobby under ECR Hajipur. Table shown there are 2630 cases of less than 8 hrs. work, 611 cases of more than $8 \mathrm{hrs}$. and less than $10 \mathrm{hrs}$. of work, 210 case of more than $10 \mathrm{hrs}$. and less than $12 \mathrm{hrs}$. of work, 65 cases of more than $12 \mathrm{hrs}$. and less than $14 \mathrm{hrs}$. of work and 62 cases of more than 14 hrs. of work.

$i v$. There is no upper limit in the railways rulebook on the number of night duties to be done by the railways' driver. Despite data from major rail accidents, pointed to the fact that most mishaps take place between early night and late morning. The weekly rest provisions for Railways' drivers are vague. Faced with a severe staff shortage(now 60,000 loco drivers and there is $20 \%$ vacancy in the 82,000 sanctioned posts), coupled with the fact that most trains run also during night hours, railways is being forced to put most of its drivers on night duty for long periods. (For instance, the Railways' driver roster for Hampi Express which collided with a stationary train suggests that the driver had run 23 trains in 19 days of which 12 were full-night, three half-night and seven full-day duties. This means the driver had undisturbed sleep in only seven days in the past three weeks. Duty of loco pilots is very much strenuous (www.indian railway driver information, 2012). Table-4, (Night Duty Hrs.), is showing the number of hrs. worked between 22:00 PM and 06:00 AM of loco-pilots in the month of Aug; 2013 of SEE (Sonpur) Lobby under ECR Hajipur. It's shown the regular and continuous night duty of railway drivers in India.

v. Regular away from Home-Station (HQ): Regular away from home-station (HQ) affects family life negatively. This can have negative impacts on their family and personal life. Table-5, (Out of HQ/Home Station), is showing the out of Home-Station (HQ) report of loco-pilots in the month of 
September (01/09/2013 to 22/09/2013) of SEE (Sonpur) Lobby under ECR Hajipur. Its shown there is total sanctioned strength of railway drivers is 211 for this lobby. Table shown the regular away from Home-Station (HQ). There are 900 cases of less than 36 hrs. out of HQ, 243 cases of more than $36 \mathrm{hrs}$. and less than 72 hrs. out of HQ, 16 cases of more than $72 \mathrm{hrs}$ and less than $96 \mathrm{hrs}$. out of HQ and 02 cases of more than $96 \mathrm{hrs}$. out of HQ.

vi. Irregularity of work and the work-life relationship: Irregular working hours are a major inconvenience for railway drivers. This irregularity affects family life and leisure activities negatively. It also causes sleep problems and provides insufficient opportunities for recovery and unwinding. Irregularity of work can have negative impacts on their family and personal life.

vii. Awareness that mistake or errors are usually irreparable and can lead to tragic consequences.

viii. The ergonomic layout of the railway driver's cab and Work environment: The heavy noise, vibration, dust pollution, excess heat, high voltage electricity in the electric locomotive and diesel smell in the diesel locomotive are contributing to early fatigue to the crew. The noise level in a diesel locomotive is about more than $\mathbf{1 0 0}$ decibels which is $\mathbf{2 5}$ decibels more than maximum allowed limit of $\mathbf{7 5}$ decibels by the Industrial Pollution Control Board. The heat, diesel smell, noise from the engine room comes to the driving cab as the doors in the driving cab are not designed sound proof. To overcome this problem the locomotive cab has to be air-conditioned so that fatigue will no attack the drivers and they can concentrate on their duties properly and ensure safety of trains. (FIRE Quartly Magazine, Aug.2012). Drivers experience difficulties with working postures and movements. In diesel locomotive, seat position is very bad. Track not seen properly while loco pilot seated. Therefore, he performs his duty always in standing position.

ix. They (Railways' Drivers) are not allowed to break for food, refreshment or answer nature's call during duty. No natural calls facilities (no toilets available) in the loco cab (Ranjan, R. and Prasad, T., 2013).

Due to high speed and continuous running train Loco-Pilots are extremely tired. Their eyes and Heart are more affected.

Table: 1. Top ten stressors among railway engine pilots:

\begin{tabular}{lcc}
\hline Stressors-in order of occurrence & Subjects \% & Controls \% \\
\hline $\begin{array}{l}\text { Postural discomfort and non spacious } \\
\text { work place }\end{array}$ & 96 & 02 \\
$\begin{array}{l}\text { Noisy work place } \\
\text { Long duties with improper rest and } \\
\text { dissatisfaction with place and service at } \\
\text { the place of intermediary rest }\end{array}$ & 95 & 14 \\
$\begin{array}{l}\text { Fear and susceptibility to accident due to } \\
\text { drowsiness caused by fatigue, tiredness }\end{array}$ & 88 & 73 \\
$\begin{array}{l}\text { and exhaustion due to job stress } \\
\text { Absence of toilet in job requiring long } \\
\text { hours of working and responsibilities of } \\
\text { thousands of life }\end{array}$ & 75 & 70 \\
$\begin{array}{l}\text { Consequences of making mistake on duty } \\
\text { very severe }\end{array}$ & 71 & 00 \\
$\begin{array}{l}\text { Stress due to long period of absence from } \\
\text { home and city and unable to maintain } \\
\text { balance between work and home. }\end{array}$ & 71 & 32 \\
$\begin{array}{l}\text { Inadequate protection from extremes of } \\
\text { temperature and rain }\end{array}$ & 70 & 10 \\
$\begin{array}{l}\text { Communication gap with administration } \\
\text { Fear of mishap and exhaustion causing } \\
\text { avoidance of duty, neglect and IODs, } \\
\text { absenteeism, over-shooting, or accident }\end{array}$ & 68 & 28 \\
\hline
\end{tabular}

Subjects: Railway engine driver (loco-pilot)

Controls: Station Managers and Station Superintendent (Station Master)

(Sumit Prakash et al; 2011)

\subsection{Railway drivers and health}

The health and fitness of railway drivers is an important issue when considering how to manage the risk of fatigue. It directly affects a railway driver's ability to deal with the stresses and demands of the job (WorkSafe, Department of Consumer and Employment Protection, 2013).

When speaking about railway drivers and how they have to fight with stress and workload, we should consider how the job influences their health conditions. The fact that railway drivers are exposed to everyday whole-body vibration, diesel exhaust (in diesel locomotives) and noise, leads to increased health risks. According to Evans and Johansson (1998) and their report in Journal Occupational Health Psychology, epidemiological data from several different countries consistently find drivers among the most unhealthy of occupational groups, particularly with respect to cardiovascular, gastrointestinal and musculoskeletal disorders. (Bigert, C., 2003). 
2.2.1 Some of the more common health problems that railway drivers may experience include:

$i$. Obesity and heart disease - Being overweight or obese is strongly related to high levels in the blood and high blood pressure. Both of these factors greatly increase the risks of having a heart attack.

ii. Diabetes - Diabetes is an illness in which an individual's blood sugar level is out of control. If not controlled, diabetes can make an individual feel fatigued. Being overweight and not exercising, strongly contribute to the development of diabetes.

iii. Sleeping problems - Sleep disordered breathing or apnoea is a serious problem for individuals that snore. In these people the windpipe collapses during their sleep resulting in too little air getting to their lungs. This wakes them up and usually wakes their partners as well. This can happen repeatedly during a night and results in poor and little sleep (WorkSafe, Department of Consumer and Employment Protection, 2013).

iv. Muscular-skeletal problems (lower part of the back, neck, shoulders, upper part of the back, knees)

v. Psychological problems (fatigue, tension, mental overload)

vi. $\quad$ Stomach and intestinal disorders

(Kompier, M.A.J., 1996).

Table: 2 . Top perceived symptoms of stress among rep* and controls:

\begin{tabular}{lclc}
\hline \multicolumn{1}{c}{ Subjects } & \multicolumn{2}{c}{ Controls } \\
\hline $\begin{array}{l}\text { Symptoms in order of } \\
\text { occurrence }\end{array}$ & $\%$ & $\begin{array}{l}\text { Symptoms in order of } \\
\text { occurrence }\end{array}$ & $\%$ \\
\hline Disrupted sexual functions & 67 & Headache & 54 \\
Muscle ache and pains & 65 & Muscle aches and pains & 41 \\
Sleep disturbances & 60 & Sleep disturbances & 40 \\
Headache & 44 & Irritability and anger & 28 \\
Stromach problems & 39 & Stomach problems & 24 \\
Irritability and anger & 30 & Disrupted sexual functions & 06 \\
Frustration and anxiety & 18 & Anorexia & 04 \\
\hline *REP - Railway Engine Pilots & & &
\end{tabular}

Subjects: Railway engine driver (loco-pilot)

Controls: Station Managers and Station Superintendent (Station Master)

(Sumit Prakash et al; 2011)

\subsection{Railway drivers and fatigue}

Fatigue is a particular problem for railway drivers. Numerous research studies have established that long and irregular work hours for drivers lead to fatigue, reduced alertness, and impaired coordination. (Belzer, M.H., 2002). The other factor of fatigue can be driving at night, since the nighttime driving is different for driving in daytime: a driver requires greater concentration because of visibility limitations. Lack of visibility may increase driver's drowsiness and fatigue (McDonald, 1984).

Fig.: 1. Fatigue has been found mostly due to:

(Sumit Prakash et al; 2011)

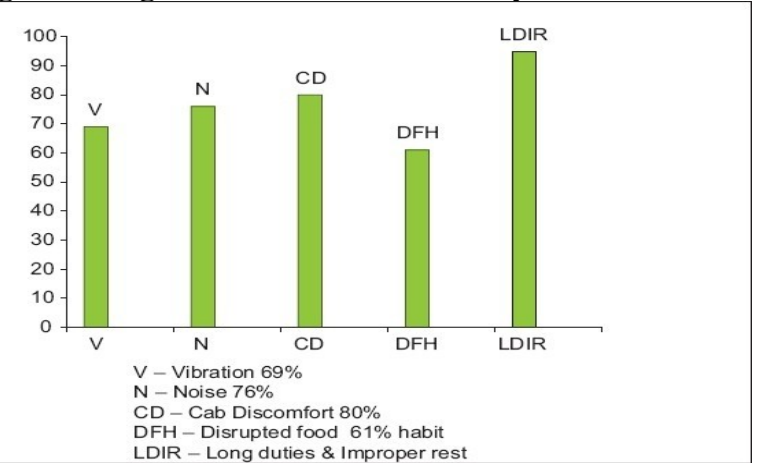

III. Findings of the study

In particular irregular and night work is a further stress factor for the loco-pilots due to its negative effects on various aspects of their lives, in particular as concerns:

i. Disturbances of the normal biological rhythms, beginning with the sleep/wake cycle;

ii. Negative effects on health and well-being, including troubles with the digestive function, nervous system (sleep deficit, anxiety, depression) and cardiovascular systems (heart diseases);

iii. Social problems, resulting from difficulties in maintaining the usual relationships both at the family and social levels. 


\section{Suggestions of the study}

$i$. Arrangement of work schedules according to psycho-physiological and social criteria: Recent studies and research have resulted in some recommendations for the design of shift work systems aimed at avoiding or reducing dangerous effects on health, well-being and efficiency of railway drivers. They can be summarized in the following points:

ii. Reducing the number of consecutive night duty as much as possible (one or two utmost), and having a day's rest after the night-duty. This prevents accumulation of sleep deficit and fatigue, and allows a quicker recovery.

iii. Keeping the work schedule rotation as regular as possible, so that the work schedule cycle will not be too long and will include some free weekends. This allows a better organization of personal, family and social life.

iv. Participation in decision making: Participation of the loco-pilots in decision making appears to be necessary to increase perceived influence, motivation, job satisfaction and performance efficiency, as well as to decrease stress and relative negative consequences.

According to these guidelines, the Italian ATC company, has adopted for many years a fast-rotating shift schedule on a six-day cycle, as follows: first day: afternoon (13:00- 20:00); second day: morning (07:0013:00); third day: night (20:00-07:00); fourth day: rest after the end of the night shift; fifth day: off; sixth day: off. This has been found to be very helpful in overcoming sleepiness and maintaining alertness and performance efficiency (Giovanni Costa, 1995).

\section{Conclusions}

Following points are concluded from the theoretical part of this paper. The aim of these points is to suggest possible solutions and tools how to improve work environment and other conditions of railway drivers in India, in order to reduce the stress caused by different factors.

i. Ergonomics of the driver's cabin, with particular reference to the position and adjustment of the seat,

ii. Leisure time activity arranged by Indian Railway (sports, physical training, musculoskeletal exercises, swimming),

iii. Psychological training: general and special relaxation, focusing, concentration training, how to cope with stress,

Management of Indian Railways must try to keep loco-pilots (railway drivers) free from various role stresses, and stress management programs should be implemented to improve the quality of life and health as being done in most of the foreign countries.

\section{Acknowledgements}

The researcher would like to express his gratitude towards his Guru (Guide) Dr. T. Prasad (National Institute of Industrial Engineering, Mumbai) for his esteemed supervisory role he is playing to utmost perfection. Researcher especially thanks him for his encouragement, invaluable help and esteemed guidance for this research study. His continuous support and encouragement is playing a key role in this research work.

\section{References}

[1]. Belzer, M.H. 2002. "Proposed changes in Motor Carrier Hours of Service Regulation: An Assessment." Transportation Research Institute, University of Michigan, U.S.

[2]. Bigert, C. 2003. "Myocardial infarction among professional drivers." Department of Occupational and Environmental Health, Stockholm Centre for Public Health, Sweden. Epidemiology,

[3]. Braaten Den J. 2000. "Occupational Stress in Mental Health Counselor.” The Graduate College, University of Wisconsin-Stout, Menomonie, Wisconsin.

[4]. Chusmir, L. H. and Franks, V. 1988. "Stress and the Woman Manager.” Training \& Development Journal, Vol. 42(10): 66-70.

[5]. Comish, R. and Swindle, B. 1994. "Managing stress in the workplace." National Public Accountant, Vol. 39(9): 24-28.

[6]. Central bureau of statistics (Statistics Netherlands, 2013 Downloaded)

[7]. Evans, G.W. and Johansson, G. 1998. "Urban Bus Driving: An International Arena for the Study of Occupational Health Psychology." Journal of Occupational Health Psychology, Vol.3, Number 2, 99-108 pg.

[8]. Erkutlu, H. V.and Chafra, J. 2006. "Relationship between Leadership Power Base and Job Stress of Subordinates: Example from Boutique Hotels." Management Research News, Vol. 29(5): 285-297.

[9]. FIRE Quartly Magazine. Aug.2012. All India Loco Running Staff Association.

[10]. Giovanni Costa 1995. “Occupational Stress and Stress Prevention in Air Traffic Control.” Institute of Occupational Medicine University of Verona, International Labour Office Geneva. (Downloaded at: www.google.com, 2013)

[11]. Holmlund-Rytkönen, M. and Strandvik, T. 2005. "Stress in Business Relationships.” Journal of Business \& Industrial Marketing, Vol. 20(1): 12-22.

[12]. Centre for Studies on Human Stress. 2007. "How to Measure Stress in Humans."

[13]. Fernand-Seguin Research Centre of Louis-H. Lafontaine Hospital Quebec, Canada.

[14]. Jorn Bakker, Leszek Holenderski, Rafal Kocielnik, Mykola Pechenizkiy, and Natalia Sidorova 2013. "Stess@work: From Measuring Stress to its Understanding, Prediction and Handling with Personalized Coaching." EIT ICT Labs, Thematic Line Health \& Wellbeing (Downloaded at: http://eit.ictlabs.eu) 
[15]. Joan Burton. Feb.2010. "WHO Healthy Workplace Framework and Model: Background Document and Supporting Literature and Practices." WHO Headquarters, Geneva, Switzerland.

[16]. Khodabakhsh Ahmadi and Kolivand Alireza. 2007. "Stress and Job Satisfaction among Air Force Military Pilots." Journal of Social Sciences, Vol. 3 (3): 159-163.

[17]. Křivohlavý, J. 2003. Psychologie zdraví, Portál, Praha.

[18]. Kloimuller, I. 2000. "The relation of age, work ability index and stress-inducing factors among bus drivers." Institute of Occupational Health Promotion, Vienna. Vol. 9, pg. 33-35.

[19]. Kompier, M.A.J.1996. "Bus drivers: Occupational stress and stress prevention." Department of Work and Organizational Psychology, University of Nijmegen, International Labour Office Geneva. (Downloaded at: www.google.com, 2013)

[20]. McDonald, N. 1984. "Fatigue, safety, and the Truck Driver". Taylor and Francis, Philadelphia.

[21]. Mary Terzian, M.S.W., Kristin A. Moore, and Hoan N. Nguyen. 2010. "Assessing Stress in Children and Youth: A Guide for Outof-School Time Program Practitioners.” Brief Research -to -Results; Trend Child, Publication \#2010-22

[22]. Manual on stress prevention for bus drivers (1996). Downloaded from: www.ilo.org/public/english/protection/safework/stress/busdrver.htm,

[23]. Nina Pološki Vokić and Ana Bogdanić. 2007. Individual differences and occupational stress perceived: a Croatian survey. Faculty of Economics and Business, University of Zagreb, Croatia, Working paper series, Paper No. 07-05.

[24]. Prakash S, Khapre P, Laha SK, Saran N. 2011. "Study to assess the level of stress and identification of significant stressors among the railway engine pilots." Indian J Occup Environ Med [serial online] 2011 [cited 2012 Aug 26]; 15:113-9. Available from: http://www.ijoem.com/text.asp?2011/15/3/113/93201

[25]. Rees, W. D. 1997. "Managerial Stress - Dealing with the Causes, Not the Symptoms." Industrial and Commercial Training, Vol. 29(2): 35-40.

[26]. Ross, G. F. 2005. "Tourism Industry Employee Work Stress - A Present and Future Crisis." Journal of Travel \& Tourism Marketing, Vol. 19(2/3): 133-147.

[27]. Rajesh Ranjan and T. Prasad. 2013. "Literature Review Report on - An Analytical Study on Working Conditions of Loco-Pilots (Railway Drivers) in India.” European Journal of Business and Management (EJBM). ISSN 2222-1905 (Paper) ISSN 2222-2839 (Online), Vol.5, No.12. www.iiste.org

[28]. Sharpley, C. F., Reynolds, R., Acosta, A., and Dua, J. K. 1996. "The Presence, Nature and Effects of Job Stress on Physical and Psychological Health at a Large Australian University.” Journal of Educational Administration, Vol. 34(4): 73-86.

[29]. Singh Ravi Kant. 2008. Life of an Assistant Loco Pilot (ALP)/Assistant Driver. All India Loco Running Staff Association (Posted on Web).

[30]. Work Safe. 2013. Downloaded. Developing a Fatigue Management Plan for Commercial Vehicle Drivers and Operator, Department of Consumer and Employment Protection, Australia, Email: safety@worksafe.wa.gov.au, www.worksafe.wa.gov.au

[31]. W.R.P.K. Fernando, M.Selvam, and E.Bennet. 2013. Downloaded. Exhaustion and Stress: an Empirical Study Among Workers in Apparel Industry of Sri Lanka. www.google scholar.com

[32]. www.indian railway driver information (2012)

[33]. www.workhealth.gov/niosh/stresswk.html

\section{Appendices:}

Table: 3. Ten Hrs. Reports:

Working Hours: Sign On/Sign Off Report of August-2013 (Retrieved on: 22/09/2013)

Zone: ECR (East Central Railway, Hajipur)

\begin{tabular}{|c|c|c|c|c|c|c|c|}
\hline S. No. & DESIG & $<8$ Hours & 8-10 Hours & 10-12 Hours & 12-14 Hours & $>14$ Hours & Total \\
\hline 1 & ALP & $\underline{704}$ & $\underline{125}$ & $\underline{36}$ & $\underline{10}$ & $\underline{16}$ & 891 \\
\hline 2 & LPG & $\underline{321}$ & $\underline{142}$ & $\underline{61}$ & $\underline{34}$ & $\underline{20}$ & 578 \\
\hline 3 & LPM & $\underline{610}$ & $\underline{124}$ & $\underline{52}$ & $\underline{14}$ & $\underline{7}$ & 807 \\
\hline 4 & LPP & $\underline{523}$ & $\underline{100}$ & $\underline{24}$ & $\underline{1}$ & $\underline{12}$ & 660 \\
\hline 5 & SALP & $\underline{463}$ & $\underline{107}$ & 37 & $\underline{5}$ & $\underline{7}$ & 619 \\
\hline 6 & SHT & $\underline{9}$ & $\underline{13}$ & $\underline{0}$ & $\underline{1}$ & $\underline{0}$ & 23 \\
\hline
\end{tabular}

Table: 4. Night Duty Hrs.

Night Duty Hrs. Report of August-2013 (Retrieved on: 22/09/2013)

Zone: ECR (East Central Railway, Hajipur)

Lobby: SEE (Sonpur)

\begin{tabular}{|c|c|c|c|c|c|c|c|c|c|c|c|c|c|c|c|c|c|c|c|c|c|c|c|c|c|c|c|c|c|c|c|c|c|c|c|}
\hline \multirow{2}{*}{$\begin{array}{l}\text { CRE } \\
\text { W ID }\end{array}$} & \multirow{2}{*}{$\begin{array}{l}\text { CREW } \\
\text { NAME }\end{array}$} & \multirow{2}{*}{$\begin{array}{l}\mathbf{P} \\
\mathbf{F} \\
\mathbf{N} \\
\mathbf{O}\end{array}$} & \multirow{2}{*}{$\begin{array}{c}\text { DES } \\
\text { G }\end{array}$} & \multicolumn{31}{|c|}{ No Of Hours Worked Between 22:00 Hours And 6:00 Hours } & \multirow{2}{*}{\begin{tabular}{|c} 
TOT \\
AL \\
HOU \\
RS \\
\end{tabular}} \\
\hline & & & & 1 & 2 & 3 & 4 & 5 & 6 & 7 & 8 & 9 & $\begin{array}{l}1 \\
\mathbf{0}\end{array}$ & $\begin{array}{l}1 \\
1\end{array}$ & $\begin{array}{l}1 \\
2\end{array}$ & $\begin{array}{l}1 \\
3 \\
\end{array}$ & $\begin{array}{l}1 \\
4 \\
\end{array}$ & $\begin{array}{l}1 \\
5\end{array}$ & $\begin{array}{l}1 \\
6 \\
\end{array}$ & $\begin{array}{l}1 \\
7 \\
\end{array}$ & \begin{tabular}{l||}
1 \\
8
\end{tabular} & $\begin{array}{l}1 \\
9 \\
\end{array}$ & $\begin{array}{l}2 \\
\mathbf{0}\end{array}$ & $\begin{array}{l}2 \\
1\end{array}$ & \begin{tabular}{l|l}
2 \\
2
\end{tabular} & \begin{tabular}{|l||}
2 \\
3
\end{tabular} & $\begin{array}{l}2 \\
4 \\
\end{array}$ & $\begin{array}{l}2 \\
5\end{array}$ & $\begin{array}{l}2 \\
6 \\
\end{array}$ & $\begin{array}{l}2 \\
7\end{array}$ & $\begin{array}{l}2 \\
8 \\
\end{array}$ & $\begin{array}{l}2 \\
9 \\
\end{array}$ & $\begin{array}{l}3 \\
\mathbf{0}\end{array}$ & $\begin{array}{l}3 \\
1\end{array}$ & \\
\hline $\begin{array}{c}\text { SEE 11 } \\
92\end{array}$ & $\begin{array}{l}\text { SADA } \\
\text { KALYAN } \\
\text { TRIPATHI }\end{array}$ & & $\underset{\mathbf{P}}{\mathbf{S A L}}$ & $\begin{array}{l}2 . \mid \\
0\end{array}$ & $\begin{array}{l}1 . \\
9\end{array}$ & $\begin{array}{l}5 . \\
5\end{array}$ & $\begin{array}{l}1 . \\
2\end{array}$ & $\begin{array}{c}0 . \\
8\end{array}$ & - & 8. & - & - & - & - & - & - & $\begin{array}{l}2 . \\
9\end{array}$ & - & - & - & - & - & - & - & $\begin{array}{c}3 . \\
1\end{array}$ & 2. & 3. & $\begin{array}{c}0 . \\
1\end{array}$ & & - & 2. & $\begin{array}{l}1 . \\
8\end{array}$ & 5. & $\begin{array}{l}4 . \\
2\end{array}$ & 40 \\
\hline $\begin{array}{c}\text { SEE11 } \\
94\end{array}$ & $\begin{array}{l}\text { NEERAJ } \\
\text { KUMAR } \\
\text { PAL } \\
\end{array}$ & & $\begin{array}{c}\text { SAL } \\
\mathbf{P}\end{array}$ & - & - & - & - & - & - & - & - & 3. & 2. & $\begin{array}{l}2 . \\
5\end{array}$ & - & $\begin{array}{l}1 . \\
3\end{array}$ & - & $\begin{array}{l}1 . \\
8\end{array}$ & $\begin{array}{l}0 . \\
6\end{array}$ & 6. & $\begin{array}{l}4 . \\
5\end{array}$ & $\begin{array}{c}2 . \\
0\end{array}$ & - & $\begin{array}{l}2 . \\
9\end{array}$ & $\begin{array}{l}2 . \\
0\end{array}$ & $\begin{array}{l}1 . \\
5\end{array}$ & 1. & - & - & - & - & - & - & - & 32 \\
\hline $\begin{array}{c}\text { SEE11 } \\
96\end{array}$ & $\begin{array}{l}\text { PAWAN } \\
\text { HEMROM }\end{array}$ & & ALP & - & - & - & - & $\begin{array}{l}2 . \\
0\end{array}$ & $\begin{array}{l}2 . \\
9\end{array}$ & 5. & $\begin{array}{l}4 . \\
5\end{array}$ & $\begin{array}{l}0 . \\
6\end{array}$ & - & $\begin{array}{l}2 . \\
9\end{array}$ & - & - & - & - & - & - & $\begin{array}{l}1 . \mid \\
9\end{array}$ & $\begin{array}{l}0 . \\
6\end{array}$ & $\begin{array}{l}5 . \\
5\end{array}$ & $\begin{array}{l}3 . \\
0\end{array}$ & - & $\begin{array}{l}3 . \\
0\end{array}$ & - & $\begin{array}{l}1 . \\
2\end{array}$ & $\begin{array}{l}5 . \\
1\end{array}$ & 1. & - & $\begin{array}{l}1 . \\
9\end{array}$ & $\begin{array}{l}6 . \\
0\end{array}$ & - & 48 \\
\hline $\begin{array}{c}\text { SEE11 } \\
97\end{array}$ & $\begin{array}{l}\text { RAJEEV } \\
\text { RANJAN }\end{array}$ & & $\begin{array}{c}\text { SAL } \\
\text { P }\end{array}$ & - & - & $\begin{array}{c}3 . \\
1\end{array}$ & & - & - & $\begin{array}{l}3 . \\
1\end{array}$ & 2. & $\begin{array}{l}2 . \\
7\end{array}$ & - & - & 3. & - & - & - & $\begin{array}{l}3 . \\
4\end{array}$ & - & - & $\begin{array}{c}3 . \\
1\end{array}$ & - & - & - & $\begin{array}{l}2 . \\
0\end{array}$ & $\begin{array}{l}0 . \\
5\end{array}$ & - & $\begin{array}{l}0 . \\
7\end{array}$ & & - & - & 2. & $\begin{array}{c}6 . \\
0\end{array}$ & 32 \\
\hline
\end{tabular}




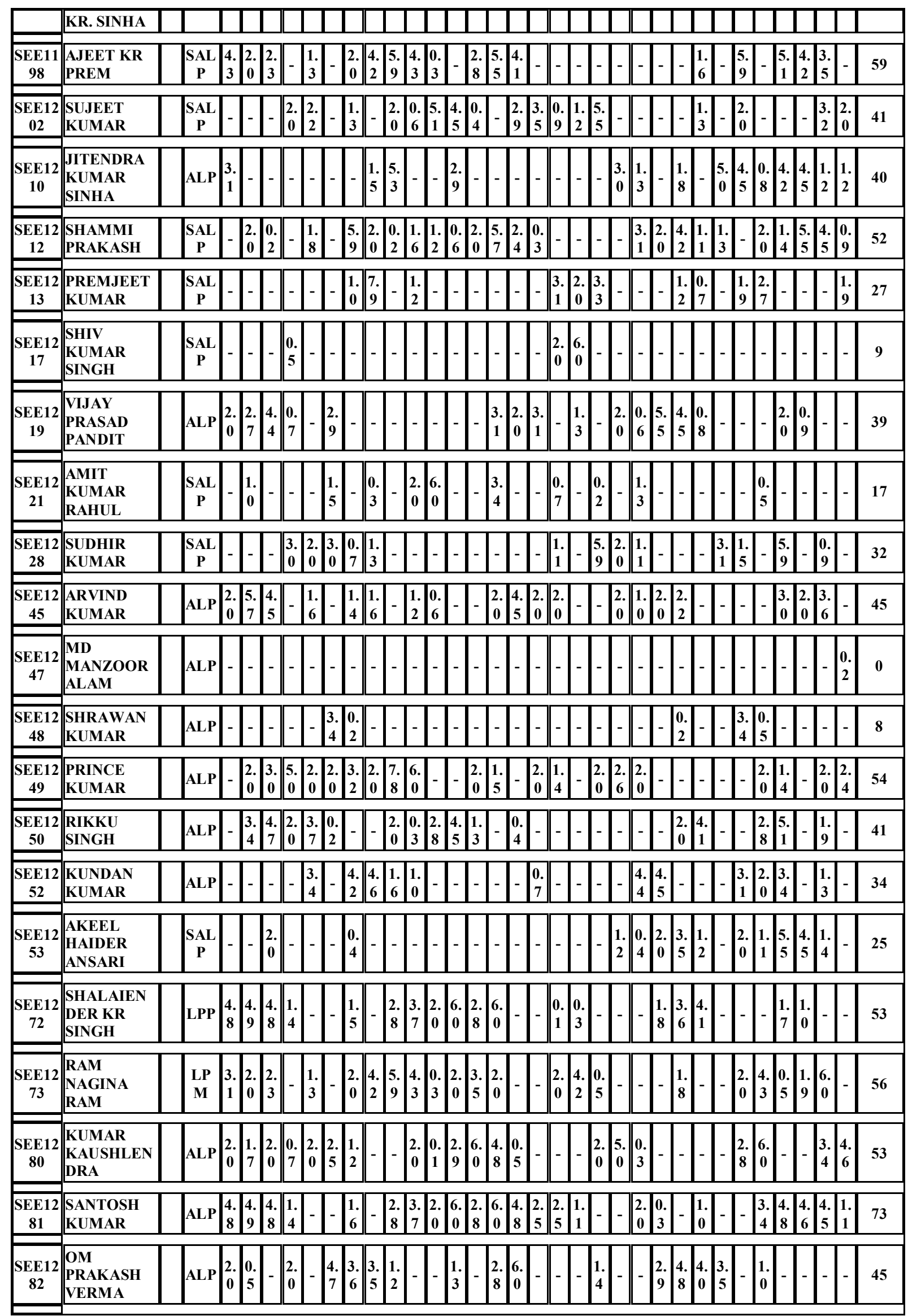


Table: 5. Out of HQ (Home Station) Report:

Slot: 01/09/2013 to 30/09/2013 (Retrieved on: 22/09/2013)

Zone: ECR (East Central Railway, Hajipur)

HQ: SEE (Sonpur)

\begin{tabular}{|c||c|c|c||c||c|c|}
\hline \multirow{2}{*}{ S. No. } & Designation & $\begin{array}{c}\text { Sanctioned } \\
\text { Strength }\end{array}$ & & \multicolumn{3}{|c|}{ No. of cases in a period of Out of Lobby (HQ) in Running } \\
\cline { 4 - 7 } & & (Cases) $<\mathbf{3 6}$ Hrs. & $\begin{array}{c}\mathbf{3 6} \text { Hrs. }>\text { (Cases) }<\mathbf{7 2} \\
\text { Hrs. }\end{array}$ & $\begin{array}{c}\text { 72 Hrs. } \\
>\text { (Cases) }< \\
\mathbf{9 6} \text { Hrs. }\end{array}$ & $\begin{array}{c}\text { (Cases) }>\mathbf{9 6} \\
\text { Hrs. }\end{array}$ \\
\hline 1 & ALP & 61 & 282 & 39 & 0 & 0 \\
\hline 2 & LPG & 55 & 28 & 38 & 13 & 2 \\
\hline 3 & LPM & 33 & 260 & 94 & 0 & 0 \\
\hline 4 & LPP & 36 & 177 & 9 & 2 & 0 \\
\hline 5 & SALP & 26 & 146 & 61 & 1 & 0 \\
\hline 6 & SLPP & 0 & 7 & 2 & 0 & 0 \\
\hline
\end{tabular}

